\title{
Eph/ephrin molecules-a hub for signaling and endocytosis
}

\author{
Mara E. Pitulescu and Ralf H. Adams ${ }^{1}$ \\ Department of Tissue Morphogenesis, Max-Planck-Institute for Molecular Biomedicine, and Faculty of Medicine, University \\ of Münster, D-48149 Münster, Germany
}

The development, homeostasis, and regeneration of complex organ systems require extensive cell-cell communication to ensure that different cells proliferate, migrate, differentiate, assemble, and function in a coordinated and timely fashion. Eph receptor tyrosine kinases and their ephrin ligands are critical regulators of cell contact-dependent signaling and patterning. Eph/ephrin binding can lead to very diverse biological readouts such as adhesion versus repulsion, or increased versus decreased motility. Accordingly, depending on cell type and context, a limited and conserved set of receptor-ligand interactions is translated into a large variety of downstream signaling processes. Recent evidence indicates that the endocytosis of Eph/ephrin molecules, together with the internalization of various associated tissue-specific effectors, might be one of the key principles responsible for such highly diverse and adaptable biological roles. Here, we summarize recent insights into $\mathrm{Eph} / \mathrm{ephrin}$ signaling and endocytosis in three biological systems; i.e., the brain, intestine, and vasculature.

Eph receptors, which have been divided into the subclasses A and B, represent the largest family of receptor tyrosine kinases (RTKs) in the animal kingdom. In humans, nine EphA (EphA1-8 and EphA10) and five EphB (EphB1-4 and EphB6) receptors are known. The extracellular part of Eph receptors contains a globular ligandbinding domain, a cysteine-rich region, and two fibronectin type III repeats. The intracellular, cytoplasmic part consists of a short juxtamembrane region with several conserved tyrosine residues, the tyrosine kinase domain, a sterile $\alpha$ motif (SAM) protein-protein interaction domain, and a C-terminal PDZ-binding motif (Fig. 1A). Based on their structural features and binding affinity for A- or B-type receptors, the ligands have also been divided into GPI-anchored ephrin-A (ephrin-A1-5 in mammals) and transmembranous ephrin-B (ephrin-B1-3) molecules (Pasquale 2005). While EphA receptors typically

[Keywords: Eph; ephrin; receptor; signal transduction; patterning; endocytosis]

${ }^{1}$ Corresponding author.

E-MAIL ralf.adams@mpi-muenster.mpg.de; FAX 49-251-70365-499.

Article is online at http://www.genesdev.org/cgi/doi/10.1101/gad.1973910. Freely available online through the Genes \& Development Open Access option. bind to ephrin-A proteins, and EphBs bind to ephrin-B ligands, there is also limited cross-binding between members of the two classes (Fig. 1A; Kullander and Klein 2002; Himanen et al. 2004; Klein 2004). In contrast to classical growth factor receptors, Eph-ephrin binding leads to bidirectional signal transduction into both the receptor cell (a process termed "forward signaling") and the ligand cell ("reverse signaling"). For the B-ephrins, this active, receptor-like signal transduction involves several highly conserved tyrosine phosphorylation sites in the cytoplasmic domain, a C-terminal PDZ motif, and the binding to several cytoplasmic adapter and PDZ domain proteins (Fig. 1B). While ephrin-As lack a cytoplasmic tail, these ligands are still capable of triggering downstream activation of Src family kinases (SFKs) and phosphoinositide 3-kinase (PI3K), which might involve a signal-transducing "coreceptor" or the clustering of plasma membrane microdomains (Davy et al. 1999; Davy and Robbins 2000; Holen et al. 2008). The neurotrophin receptors Trk/B and p75 might serve as such coreceptors, and it has been shown that their signaling is enhanced by interactions with ephrin-A ligands in cis (Lim et al. 2008; Marler et al. 2008).

In many-but by no means all-settings, Eph/ephrin signaling interactions generate repulsive signals that, for example, help to guide growing neuronal axons and migrating cells to their appropriate targets (Fig. 1C). The sorting and segregation of mixed Eph- and ephrin-expressing cell subpopulations is another role that has been observed in a variety of biological processes. In this context, cells will move around with the aim of minimizing Eph/ephrin interactions so that Eph-positive and ephrinexpressing cells preferentially end up in separate clusters or tissue domains (Fig. 1C; Xu et al. 1999, 2000; Batlle et al. 2002; Compagni et al. 2003; Davy et al. 2004, 2006; Kim et al. 2008; Passante et al. 2008; Jorgensen et al. 2009).

Comprehensive and up-to-date reviews of Eph/ephrin signaling in cancer, structural features, and binding interfaces, and its role in the entry of Nipah and Hendra paramixoviruses have been published elsewhere (Himanen et al. 2007; Maisner et al. 2009; Pasquale 2010).

\section{Eph/ephrin signaling modes and biological effects}

In addition to the binding of Eph/ephrin molecules in trans, cis interactions between receptors and ligands 



Figure 1. Eph/ephrin structure, signaling, and mechanism of action. (A) Domain organization of Eph receptors and ephrin ligands. Cysteine (Cys)-rich, fibronectin (FN) type III, and SAM domains; transmembrane (TM) regions; and tyrosine phosphorylation sites $(\mathrm{Y})$ are indicated. EphA receptors typically bind ephrin-A (GPI-anchored) ligands, and EphB receptors bind ephrin-Bs (arrows). There is limited cross-talk between members of different classes (dashed arrows). (B) Eph/ephrin interactions in trans lead to bidirectional signal transduction. EphA and ephrinA coexpression in cis impairs receptor activation. $(C)$ Eph/ephrin interactions frequently transduce repulsive signals important for cell migration and cell sorting. $(D)$ Binding Eph/ephrin molecules form heterotetramers to initiate the signal, oligomerize, and further assemble in large receptor clusters that expand laterally trough Eph-Eph cis interactions. (E) Metalloprotease association with the EphA/ephrin-A complex leads to cleavage of the ligand, endocytosis of the complex, and cell-cell repulsion. $(F)$ Eph/ ephrin interaction can lead to repulsion also by trans-endocytosis of the complexes in a forward or reverse direction.

expressed in the same cell have been reported (Egea and Klein 2007). Cis binding does not lead to active signaling, but rather seems to interfere with receptor activation by the ephrin-A ligand presented on surrounding cells (Fig. 1B; Yin et al. 2004; Carvalho et al. 2006). This cis inhibition model can explain how partially overlapping expression of EphAs and ephrin-As can generate gradients of active, signaling-competent receptors in the developing visual system (Hornberger et al. 1999; Carvalho et al. 2006; Flanagan 2006). However, it has also been reported that coexpressed EphA/ephrin-A molecules segregate into distinct membrane domains with opposing functional roles in cell adhesion and repulsion (Marquardt et al. 2005). Segregation would obviously limit the potential of cis interactions of Ephs and ephrins and offers an alternative explanation for the modulation of functional effects by the ratio of coexpressed receptor and ligand molecules.

In addition to cis and trans interactions, several alternative modes of modulating Eph/ephrin signaling have been proposed. For example, high concentrations of the ligand ephrin-A2 presented in trans inhibit the growth of retinal axons, whereas low concentrations are growthpromoting (Hansen et al. 2004). Thus, differences in the local levels of Eph/ephrin signaling interactions might lead to distinct biological effects. Likewise, short splice variants of the receptor EphA7 lacking the cytoplasmic kinase domain can convert repulsive cellular responses into adhesion (Holmberg et al. 2000). Remarkably, some of the activities of Ephs and ephrins appear not to rely on physical receptor-ligand interactions. For instance, activation of EphA3 by ephrin-A5 in trans leads to the formation of large receptor clusters that expand laterally through Eph-Eph cis interactions (Fig. 1D; WimmerKleikamp et al. 2004). This signaling cluster propagation is ephrin-independent, which might enable the amplification of an initially small signal generated by cell contact and Eph-ephrin binding. It has also been proposed that the receptor EphB4 can inhibit integrin-mediated cell adhesion independently of its main (or sole) binding partner, ephrin-B2 (Noren et al. 2009). Conversely, cultured ephrin-B2-deficient or -overexpressing cells show contact-independent migration and adhesion defects, suggesting that the ligand can also signal in a cellautonomous mode in the absence of receptor binding (Foo et al. 2006; Bochenek et al. 2010).

Cleavage of Eph receptors and ephrins by ADAM family metalloproteases and $\gamma$-secretase proteases also hugely affects the biological effect of Eph/ephrin interactions (Hattori et al. 2000; Janes et al. 2005, 2009; Georgakopoulos et al. 2006; Tomita et al. 2006; Litterst et al. 2007). Ephrin-A2 can be released from the plasma membrane after cleavage by ADAM10/Kuzbanian (Fig. 1E; Hattori et al. 2000). A cleavage-resistant version of ephrin-A2 strongly delays the repulsion of Eph receptor-presenting axon growth cones, which indicates that proteolytic processing helps to terminate Eph/ephrin-mediated cell interactions. The same study has also suggested that ADAM10 constitutively binds to ephrin-A2 in cis, while cleavage is triggered only after EphA binding (Hattori et al. 2000). However, it has also been shown that ADAM10 can stably associate with EphA3 so that ephrin-A2 is cleaved in trans and therefore only after binding to EphA3 (Janes et al. 2005). Since the ADAM10 recognition motif is conserved in the extracellular domain of all vertebrate ephrins, cleavage might be of general relevance for Eph/ ephrin interactions and the resulting cell behavior.

\section{Internalization by endocytosis}

Another mechanism used by cells to terminate Eph/ ephrin interactions is endocytosis. During this process, the intact receptor-ligand complex and, possibly, associated 
cytoplasmic proteins, together with the surrounding plasma membrane, can be internalized into the Eph- or ephrin-expressing cell (Mann et al. 2003; Marston et al. 2003; Zimmer et al. 2003; Lauterbach and Klein 2006). The exact mechanistic basis for this unusual processtermed trans-endocytosis-remains incompletely understood (Fig. 1F). Nevertheless, double-membrane-coated intracellular structures, which one would predict for the combined internalization of interacting plasma membrane regions, can be seen in the rat hippocampus by electron microscopy (Spacek and Harris 2004). Trans-endocytosis terminates adhesion and, like ligand proteolytic cleavage, enables cell retraction. It is noteworthy that the direction of endocytosis is determined by Eph/ephrin-mediated signal transduction. Signaling-deficient EphB2, lacking the cytoplasmic region, directs the internalization of the receptor-ligand complex into the adjacent, ephrin-B1expressing cell. In contrast, the reverse scenario, full-length EphB2 and truncated ephrin-B1, leads to trans-endocytosis into the receptor cell. Simultaneous truncation of EphB2 and ephrin-B1 prevents internalization and strongly prolongs cell adhesion (Zimmer et al. 2003). Both receptorligand complex internalization and cell retraction require actin polymerization and activity of the small GTPase Rac1 (Marston et al. 2003). Moreover, signaling from the internalized Eph/ephrin complex persists after trans-endocytosis, suggesting that active signal transduction can be shifted into one or the other interacting cell (Marston et al. 2003).

The clathrin pathway has been linked to ephrin-B1 endocytosis. Treatment of cells expressing green fluorescent protein (GFP)-tagged ephrin-B1 with soluble, recombinant EphB1/Fc fusion protein triggers ligand clustering and internalization into clathrin-coated vesicles (Parker et al. 2004). Internalized ephrin-B1 colocalizes with the early endosome marker EEA1 (Early Endosome Antigen 1 ), and the uptake of the ligand is blocked by dominantnegative dynamin (Parker et al. 2004). These features suggest that classical, clathrin-dependent endocytosis is responsible for ephrin-B (reverse) internalization. However, at least in the uptake of EphB receptors from the cell surface, caveolae might also be involved. Caveolae are plasma membrane invaginations with a special lipid composition and roles in mechanosensing and endocytosis (Bruns and Palade 1968; Yu et al. 2006). Ephs are concentrated in caveolae, and the receptor EphB1 associates with the protein caveolin-1 (Vihanto et al. 2006). These few reports indicate that further work is required to elucidate the full molecular mechanism of Eph/ephrin endocytosis.

\section{Eph/ephrin endocytosis-lessons from the nervous system}

Ephs and ephrins are understood best as patterning and axon guidance molecules in the nervous system (Flanagan and Vanderhaeghen 1998; Kullander and Klein 2002). The motile growth cones at the distal ends of growing axons respond to repulsive or attractive cues in their environment to ensure the proper wiring of the nervous system (Fig. 2A; Chisholm and Tessier-Lavigne 1999; Yu and
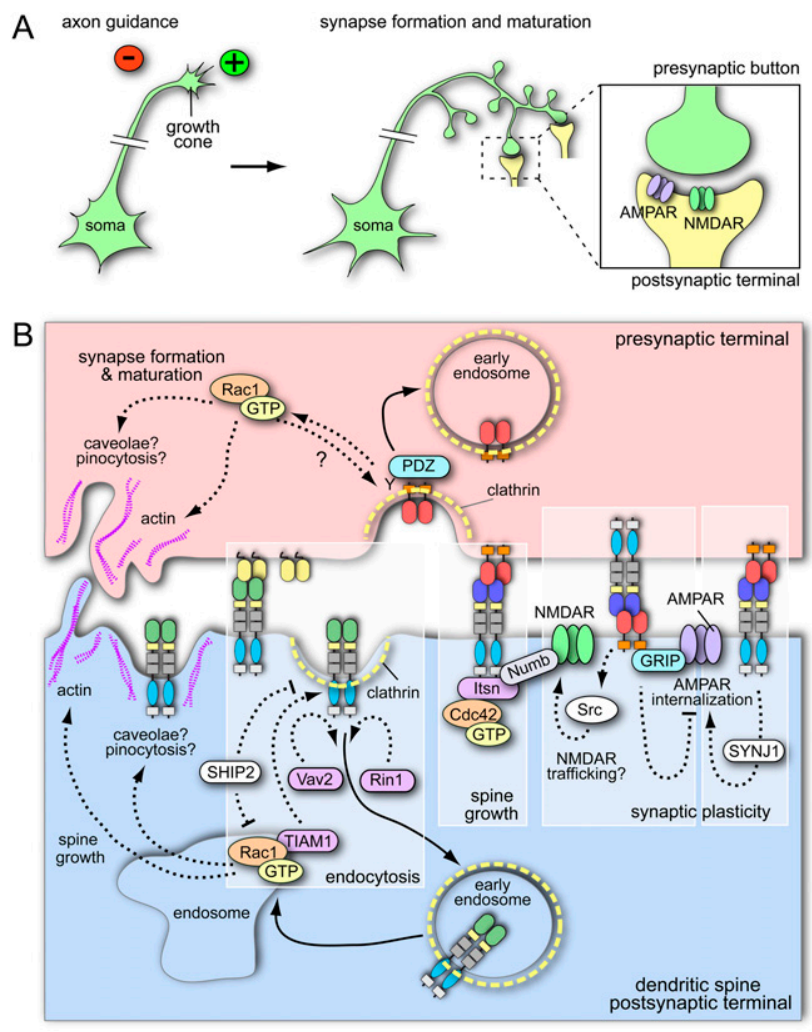

Figure 2. Eph/ephrin signaling and endocytosis in the nervous system. $(A)$ The growth cones of extending axons are guided by attractive $(+)$ and repulsive $(-)$ cues. Follwing synapse formation and maturation, neurotransmitters are released from the presynaptic side and activate receptors (e.g., AMPAR or NMDAR for excitatory synapses) located in the postsynaptic terminal. (B) In the postsynaptic cell, Eph receptor endocytosis is clathrinmediated and regulated by the activation of Vav2 (a GEF for Rho family GTPases), Rin1 (a GEF for endosomal Rab5 GTPase), and TIAM1 (a GEF for Rac1 GTPase). Receptor endocytosis and Rac1 GTPase activity are inhibited by the lipid phosphatase SHIP2. Rac1 GTPase (which can get locally activated in endosomes) modifies actin cytoskeleton and has been linked to caveolar internalization or pinocytosis. A similar, Racl GTPdependent mechanism might apply for ephrin-B reverse endocytosis in the presynaptic cell. Linked to forward Eph signaling, Numb (a clathrin adapter) regulates dendritic spine morphogenesis by coupling activated Eph and intersectin (a GEF for Cdc42). Numb regulates not only spine growth, but also synaptic plasticity, probably through Eph-dependent NMDA receptor endocytosis. EphB forward signaling and endocytosis regulates synaptic plasticity by phosphorylation of synaptojanin and enhanced internalization of AMPAR. Postsynaptic ephrin-B reverse signaling leads to GRIP binding and increases AMPAR surface presentation. Some of the mechanisms of endocytosis were derived from studies using soluble Fc fusion proteins and are not validated by cell-cell stimulation experiments.

Bargmann 2001; Grunwald and Klein 2002). The activation of Eph receptors in growing neurons typically, but not always, leads to a growth cone collapse response and retraction from an ephrin-expressing substrate (Poliakov et al. 2004; Pasquale 2005; Klein 2009). Ephs and ephrins are sometimes expressed in gradients so that neurons, 
depending on the actual levels of Eph/ephrin interactions, can respond differentially to repellent cues (Klein 2004). Once axons have reached their targets, the growth cone is converted into a presynaptic terminal that contains neurotransmitters and releases synaptic vesicles upon stimulation (Fig. 2A). The postsynaptic (dendritic) site is highly enriched in neurotransmitter receptors but also in scaffolding and signaling proteins. For excitatory, glutamatergic synapses (using NMDA, AMPA, and other glutamate-binding receptors), maturation involves actin-rich dendritic spines that each forms synaptic connections with a single axon terminal. Spine formation and retraction is a highly dynamic process and is also linked to synaptic plasticity (Klein 2009). All of the processes above involve Eph/ephrin molecules (Lai and Ip 2009) and are strongly linked to internalization processes.

Eph/ephrin signaling is frequently coupled to activity regulation of small Rho family GTPases such as Rac, Rho, or Cdc42 that connect bidirectional receptor-ligand interactions to changes in the actin cytoskeleton (Noren and Pasquale 2004; Groeger and Nobes 2007). The activity of Rac is required for Eph/ephrin-induced membrane ruffling, trans-endocytosis, and cell repulsion (Marston et al. 2003). Cdc42 promotes the formation of filopodia and dendritic spines (Irie and Yamaguchi 2002; Nishimura et al. 2006). Rho-A regulates actin dynamics, cell contractility, and phagocytosis, and is involved in Ephinduced growth cone collapse. The latter is mediated by ephexins, which are cytoplasmic proteins that interact with Eph RTKs and have guanine nucleotide exchange factor (GEF) activity enabling the activation of Rho (Shamah et al. 2001; Sahin et al. 2005). Other GEFs for Rho family GTPases, the Vav proteins (Vav1-3), are also activated downstream from Eph receptors (Fig. 2B; Cowan et al. 2005). Vav2 can bind the intracellular juxtamembrane region of EphA4 and EphB2 via its Src homology 2 (SH2) domain and gets tyrosine-phosphorylated in response to ligand (ephrin-A1 and ephrin-B1, respectively) binding. This phosphorylation step activates GDP/GTP exchange and positively regulates Eph/ephrin endocytosis (Cowan et al. 2005). Vav2/Vav3 double-knockout mice develop axon guidance defects. Cultured neurons from these mutants no longer show growth cone collapse and lack Eph/ephrin endocytosis in response to ephrin-A1 stimulation (Cowan et al. 2005).

TIAM1, a GEF with specificity for Rac1, is critical for Eph/ephrin-mediated neurite outgrowth and dendritic spine development (Tanaka et al. 2004; Tolias et al. 2007). TIAM1 also plays an important role in Eph/ephrin endocytosis (Fig. 2B; Yoo et al. 2010). Stimulation of cultured cells expressing EphA8 with ephrin-A5 induces clathrindependent endocytosis of the receptor-ligand complex. Activation of TIAM1 requires binding of the GEF to the juxtamembrane region of EphA8. Accordingly, deletion of this region, which is highly conserved within the Eph family, or down-regulation of TIAM1 expression compromises EphA8/ephrin-A5 internalization (Yoo et al. 2010). It is noteworthy that RTK signaling triggers the local activation of TIAM1 and Rac1 in endosomes, which in turn leads to spatially restricted actin polymerization and the forma- tion of cellular protrusion and controls directional migration (Palamidessi et al. 2008). Whether this mechanism can also explain the roles of Eph receptors in cell migration remains to be explored.

A negative regulator of Rac1, the GTPase-activating protein (GAP) $\alpha$-chimerin, acts downstream from EphA4 after ephrin-B3 binding. This interaction mediates growth cone collapse in cultured neurons. Accordingly, $\alpha$-chimerin mutant mice show axon guidance defects affecting motor neurons trajectories (Iwasato et al. 2007).

Rin1 (Ras/Rab interactor 1) is a GEF for the endosomal GTPase Rab5, which is known to control the fusion of endocytic vesicles and early endosomes. Rin 1 is expressed in mature excitatory neurons and, like Vav, binds EphA4 with its SH2 domain. The GEF gets tyrosine-phosphorylated in response to EphA4 activation and positively regulates the internalization of the receptor into Rab5positive endosomes. EphA4 and Rin1 control neuronal plasticity in opposite ways, suggesting that Rin1 antagonizes EphA4. EphA4 endocytosis is reduced in Rin $1^{-/-}$ cultured explants from lateral amygdala, indicating that the two molecules might also be functionally linked in vivo (Fig. 2B; Deininger et al. 2008).

SHIP2 (Src Homology Inositol Phosphatase-2), a lipid phosphatase that dephosphorylates phosphatidylinositol 3,4,5-trisphosphate (PIP3) and thereby suppresses PI3K signaling, is a negative regulator of ligand-induced Eph receptor endocytosis (Fig. 2B; Zhuang et al. 2007). SHIP2 is recruited to the SAM domain of ligand-bound, active EphA2. Overexpression of SHIP2 or the administration of PI3K inhibitor reduces EphA internalization in cultured cells, whereas siRNA knockdown of SHIP2 has the opposite effect. SHIP2 function and EphA2 endocytosis are linked to the GTPase Rac1. EphA2 receptor increases Rac1 activity, which requires PI3K signaling (BrantleySieders et al. 2004). EphA2-induced Rac1 activation is increased in SHIP2 knockdown cells with elevated PIP3 levels (Zhuang et al. 2007). Although the link between SHIP2 and EphA2 endocytosis has been established in cancer cells, SHIP2 is expressed in many cell types and might well control Eph activity in the nervous system.

While it appears that Rac1 signaling generally regulates Eph/ephrin internalization positively (Marston et al. 2003; Zhuang et al. 2007), the exact link to the clathrin endocytosis machinery remains unclear. Likewise, an involvement of other modes of internalization-like caveolae or pinocytosis, which are positively regulated by Rac signaling - has not been ruled out (Fig. 2B). As small GTPases are also activated downstream from B-class ephrins (Nakada et al. 2006; Xu and Henkemeyer 2009; Bochenek et al. 2010), GEFs might be good candidates for the regulation of reverse endocytosis into the ligand cell.

\section{Endocytosis in synaptogenesis and plasticity}

Another important regulator of clathrin-mediated endocytosis that has been linked to Eph/ephrin signaling and internalization is the adapter molecule Numb. Numb contains a phosphotyrosine-binding domain that interacts with proteins containing an NPXY motif and thereby 
links this cargo to the AP2 adapter complex and clathrin (Santolini et al. 2000). Numb and the related Numb-like control neural progenitor maintenance, differentiation, and cortical morphogenesis (Petersen et al. 2002; Li et al. 2003). In cultured hippocampal neurons, Numb accumulates in growing neurites and regulates axon guidance, which involves the endocytosis of the neuronal cell adhesion molecule L1 (Nishimura et al. 2003). Stimulation of cultured neurons with soluble, recombinant ephrin-B1 protein induces dendritic spine formation and maturation, which depends on the presence of Numb. This effect is mediated by postsynaptic Eph receptor activation, as Numb forms a complex with NMDA receptor and ephrin-B1-bound EphB2 (Fig. 2B; Nishimura et al. 2006). Another critical step is binding of Numb to intersectin (a GEF for Cdc42), which leads to Cdc42 activation, the formation of dendritic protrusions, and spine elongation (Irie and Yamaguchi 2002; Nishimura et al. 2006). In line with these findings, the Drosophila homolog of intersectin, Dap160, also has a role in synaptic development and endocytosis (Koh et al. 2004; Marie et al. 2004).

As mentioned above, the strength of functional synapses-i.e., their responsiveness to stimulation and quantity of neurotransmitter release-is modulated in processes such as learning and memory storage. While synaptic plasticity remains incompletely understood, important roles have been attributed to the modulation of the axon terminal and the function of neurotransmitter receptors. Synaptojanin 1, a polyphosphoinositide phosphatase, controls the internalization of postsynaptic AMPA receptor (Gong and De Camilli 2008), a process that has been linked to Eph/ephrin signaling (Fig. 2B). Ephrin-B2 stimulation of EphB2 in cultured neuroblastoma-like cells or hippocampal neurons leads to tyrosine phosphorylation of synaptojanin 1 (Irie et al. 2005). This phosphorylation takes place in the proline-rich domain (PRD) and inhibits the interactions with the SH3 domain of endofilin, a presynaptic BAR (named after the proteins Bin-AmphiphysinRvs) domain-containing protein controlling membrane curvature (Hopper and O'Connor 2005). Binding of endophylin to the PRD domain stimulates the $5^{\prime}$-phosphatase activity of synaptojanin 1 and thereby triggers the hydrolysis of phosphatidylinositol 4,5-biphosphate (PIP2) to phosphatidylinositol 4-phosphate (PI4P). Once this process is inhibited by EphB2 signaling, PIP2 levels go up, which in turn promotes clathrin-mediated endocytosis and transferrin uptake. In line with these findings, mutations in the Eph kinase or the PRD domain of synaptojanin 1 block the increase of transferrin uptake and prevent the uptake of AMPA receptor in hippocampal neurons (Irie et al. 2005). Interestingly, EphB2-ephrin-B2 interactions not only promote endocytosis, but also impair the transfer of internalized cargo-in this case, the protein transferrin-into endosomes (Irie et al. 2005). Thus, Eph signaling controls two distinct processes in the endocytic machinery in the opposite fashion, the early and the late phases of clathrinmediated endocytosis.

While the findings above suggest that B-class ephrins mainly act presynaptically, ephrin-B2 also controls dendritic spine morphogenesis, synapse formation, and syn- aptic plasticity on the postsynaptic side (Grunwald et al. 2004; Segura et al. 2007). Some of these functions have been linked to the regulation of AMPA receptor trafficking (Fig. 2B; Essmann et al. 2008). Stimulation of cultured hippocampal neurons with soluble, recombinant EphB4 fusion protein stabilizes AMPA receptor at the cell surface. In contrast, the receptor is constitutively internalized and synaptic transmission is reduced in neurons lacking ephrin-B2 (Essmann et al. 2008). Both ephrin-B2 and AMPA receptor interact with and are bridged by the multi-PDZ domain protein GRIP (glutamate receptorinteracting protein). The binding of GRIP to ephrin-B2 is induced by Eph receptor binding and involves the phosphorylation of a serine residue in the proximity of the PDZ-binding motif at the $\mathrm{C}$ terminus of the ligand. Accordingly, rescue of ephrin-B2 knockout neurons with wild-type ephrin-B2, but not a point mutant lacking the serine phosphorylation site, can restore AMPA receptor surface presentation (Essmann et al. 2008). Besides GRIP, the PDZ domain proteins PICK1 and syntenin have been identified as binding partners of various glutamate receptor subunits and Eph/ephrin molecules (Torres et al. 1998; Bruckner et al. 1999; Hirbec et al. 2002, 2003; Essmann et al. 2008; McClelland et al. 2009). Interestingly, serine (Ser 880) phosphorylation of the AMPA receptor subunit GluR2 by protein kinase $\mathrm{C} \alpha$ also interferes with PDZ (PICK1 and GRIP) binding and thereby decreases the constitutive surface expression and recycling of internalized GluR2 (Lu and Ziff 2005). Ser 880 phosphorylation seems to be suppressed by ephrin-B2 and is therefore increased in knockout hippocampal neurons lacking the transmembrane ligand (Essmann et al. 2008).

These examples show that Eph/ephrin molecules have very versatile roles in the developing and adult nervous system. Many of these functions involve the positive or negative regulation of endocytosis and trafficking. As we show below, internalization might be a general mechanism by which Eph/ephrin molecules control complex and highly diverse biological processes.

\section{Cell positioning in the gastrointestinal tract}

In the gastrointestinal tract, processes such as cell division, differentiation, migration, and patterning are critical not only during development, but throughout adult life due to the very high rate of cell replacement in the epithelial lining of the intestine (Crosnier et al. 2006). This epithelium forms during embryogenesis in the mouse, and proliferation becomes confined to the pockets between the finger-like villi, which protrude into the lumen of the intestine. In postnatal life, the intervillus pockets develop into crypts, which contain stem cells together with transient populations of yet undifferentiated progenitors (Fig. 3A). Differentiated epithelial cells display distinct patterns of migration. Paneth cells, which provide antimicrobial defense in the small intestine, move toward the bottom of the crypt, whereas mucus-secreting Goblet, hormone-producing enterendocrine, and adsorptive cells migrate upward into the villi (Casali and Batlle 2009). Migratory behavior and proliferation are tightly coupled. 


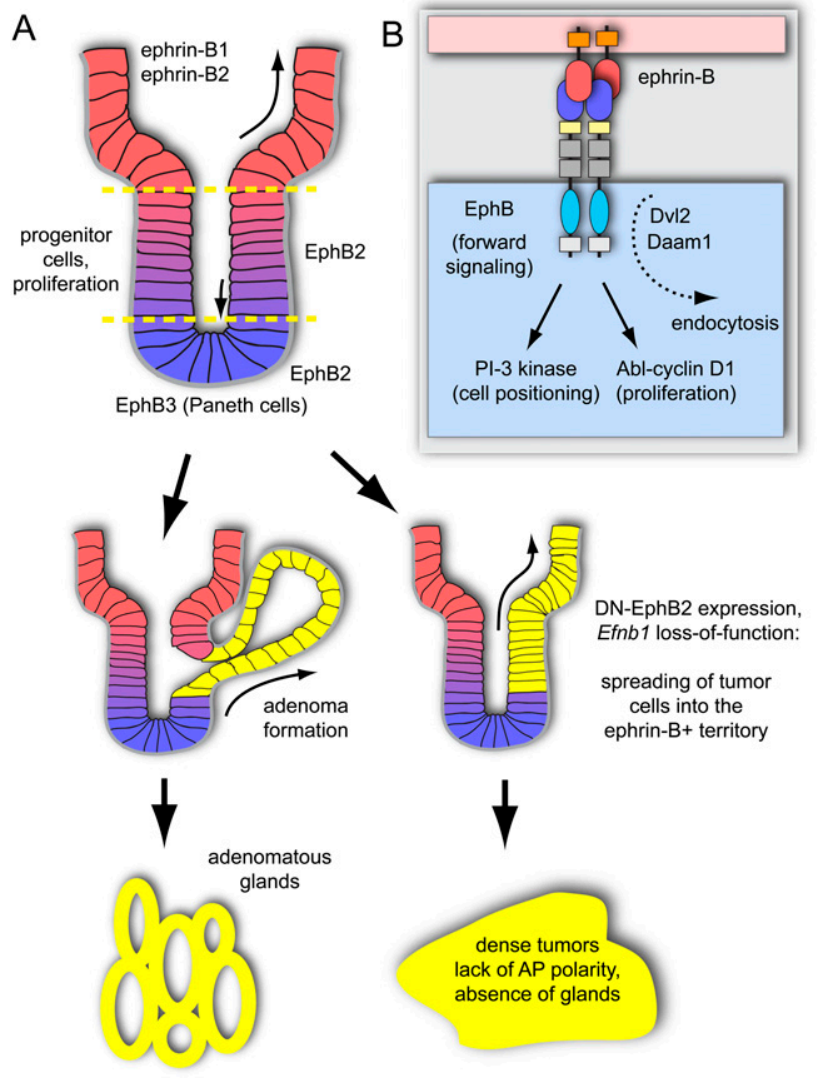

Figure 3. Eph/ephrin signaling regulates intestinal cell positioning and proliferation. (A) EphB2-positive stem and progenitor cells are located near the bottom (lower dashed line) of the intestinal crypts, while ephrin-B1/ephrin-B2-positive differentiated epithelial cells are concentrated at the crypt-villus boundary (upper dashed line). In the small intestine, EphB3-expressing Paneth cells are found at the crypt bottom. Constitutive activation of the Wnt pathway in $A p c^{M i n}$ mice leads to epithelial evaginations near the crypt-villus junctions and development of adenomatous polyps (yellow). When Eph/ephrin interactions are compromised, tumor cells spread into the villi, and more advanced colorectal cancers, which lack a glandular structure, develop. $(B)$ Intestinal cell sorting and positioning involves PI3K activity downstream from Eph/ephrin signaling. Cell proliferation is promoted by Abl kinase and cyclin D1. The proteins Dvl and Daam link Eph endocytosis and Wnt signaling.

Cells reaching the upper crypt boundary stop cycling, begin their differentiation, and enter the villus.

Stem cell maintenance and progenitor cell proliferation in the intestine are under the control of canonical Wnt signaling involving $\beta$-catenin and TCF/LEF family transcription factors (Crosnier et al. 2006; van der Flier and Clevers 2009). Proliferation in the crypts is compromised in mice lacking critical Wnt pathway components (van de Wetering et al. 2002). In contrast, loss of the tumor suppressor APC, which normally targets $\beta$-catenin for destruction, increases $\beta$-catenin levels and leads to crypt enlargement and the amplification of undifferentiated progenitor cells in mouse models or in the vast majority of human intestinal cancers (Sansom et al. 2004; Clevers and Batlle 2006).
Cell positioning along the crypt-villus axis and thereby exposure to Wnt signals are controlled by Eph/ephrinmediated interactions between epithelial cells (Batlle et al. 2002, 2005). Wnt positively regulates expression of EphB2 and EphB3, and receptor-positive cells are found in intervillus pockets and, later, in crypts (Batlle et al. 2002; van de Wetering et al. 2002). Conversely, Wnt signaling represses expression of ephrin-B1, and distribution of the ligand is largely complementary to EphB receptors (Batlle et al. 2002; van de Wetering et al. 2002). In newborn mice, ephrin-B1 labels most of the intestinal epithelium, with the exception of the bottommost cells in the intervillus pockets. In the adult, ephrin-B1 and ephrin-B2 expression is strongest at the villus-crypt boundary (Batlle et al. 2002). Indicating an important sorting function in the small intestine, these boundaries are blurred in newborn $E p h B 2 / E p h B 3$ double-knockout mice, so that proliferating and differentiated cells intermingle (Batlle et al. 2002). In the adult, Paneth cells preferentially express EphB3 and proliferating progenitor cells are positive for EphB2. In line with these expression patterns, positioning of Paneth cells is disrupted in mice lacking EphB3 but not in EphB2 mutants. In the absence of EphB2 and EphB3, or in transgenic mice expressing a dominant-negative receptor in the intestinal epithelium, ephrin-B1-positive cells scatter along the crypt-villus axis (Batlle et al. 2002). At the same time, proliferating cells are no longer confined to the lateral crypts (Holmberg et al. 2006). In addition to its role in cell sorting, EphB2 directly controls progenitor cell proliferation and cell cycle re-entry in a ligand-dependent fashion (Holmberg et al. 2006).

As mentioned above, constitutive activation of the Wnt pathway leads to the formation of adenomas and colorectal cancer (Clevers and Batlle 2006). Apc ${ }^{\mathrm{Min}}$ (multiple intestinal neoplasia) mice carrying a truncated $A p c$ allele are widely used as a colon cancer model. An early step in the development of adenomatous polyps in these animals is the growth of epithelial evaginations at the crypt-villus junction (Fig. 3A). The pattern of this process is controlled by EphB/ephrin-B interactions (Cortina et al. 2007). In Apc mutants lacking epithelial ephrin-B1, EphBpositive tumor cells no longer form evaginations and can spread along the villus axis (Fig. 3A). This has important implications for cancer progression: Tumorigenesis is accelerated, tumor burden is increased, and the normal glandular structure of adenomas is disrupted in ephrinB1-deficient Apc mice (Cortina et al. 2007). Later in colorectal cancer progression, the expression of receptors like EphB2 and EphB4 is lost despite constitutive $\beta$-catenin activation (Batlle et al. 2005). Lack of EphB3 or EphB4 or overexpression of a dominant-negative EphB2 receptor in $A p c^{M i n}$ mice causes accelerated colorectal tumorigenesis and the formation of aggressive adenocarcinomas, which suggests that EphBs act as tumor suppressors (Batlle et al. 2005; Dopeso et al. 2009). Remarkably, distinct EphB2 downstream signaling activities control cell positioning and cell cycle regulation in the intestine (Genander et al. 2009). Cell sorting does not require EphB2 kinase activity but involves PI3K signaling. In contrast, the regulation of cell proliferation is 
kinase-dependent and involves the downstream activation of the Abelson tyrosine kinase and up-regulation of the cell cycle regulator cyclin D1. In carcinomas, cyclin D1 expression becomes uncoupled from EphB signaling so that high proliferation is maintained even when EphB expression is lost (Genander et al. 2009).

Connections between Wnt and Eph/ephrin signaling have been described in numerous tissues and morphogenetic processes (Tanaka et al. 2003; Kida et al. 2007). Dishevelled proteins (Dvl), which are also essential components of the Wnt signaling pathway, form complexes with EphBs and the ligand ephrin-B1, leading to bidirectional signal transduction, activation of RhoA and Rho kinase, and cell repulsion in Xenopus embryos (Tanaka et al. 2003). Daam1 (dishevelled-associated activator of morphogenesis), a protein involved in noncanonical Wnt signaling and the regulation of planar cell polarity, forms a complex with phosphorylated Eph receptor and Dishevelled 2 (Kida et al. 2007). This complex gets internalized in a dynamin-dependent fashion, a process that is essential for convergent extension of the zebrafish notochord and normal body axis formation. Future work will have to address whether similar links between Eph receptor endocytosis and Wnt signaling are also relevant in the gastrointestinal tract and, in particular, the sorting and organization of cells within the epithelial sheet.

\section{Regulation of blood vessel morphogenesis by Eph/ephrin signaling}

The formation of blood vessels starts early in the developing mouse embryo, and blood circulation becomes indispensable for growth and survival around midgestation. Some vascular structures, like the dorsal aorta (DA) and the first primitive vascular plexus in the yolk sac, form by vasculogenesis; i.e., the de novo assembly of endothelial tubules by progenitor cells (angioblasts) (Risau and Flamme 1995). Later, the yolk sac vasculature remodels into a hierarchically organized vascular bed consisting of arteries, veins, and capillaries, the latter of which mediate the exchange of gases, nutrients, and waste products with the surrounding tissue (Fig. 4A). This remodeling of vessels and the formation of new capillaries by sprouting from the existing vasculature, which is the predominant mode of vessel growth later in development as well as in regenerative or pathological neovessel formation in the adult, are summarized under the term angiogenesis (Risau 1997).

Ephrin-B2 and the receptor EphB4 are the Eph/ephrin molecules that appear most relevant in the vasculature. Knockout mice lacking either ephrin-B2 or EphB4 show severely compromised angiogenesis, fail to remodel their yolk sac vasculature, and die at midgestation (Wang et al. 1998; Adams et al. 1999; Gerety et al. 1999; Gerety and Anderson 2002). Ephrin-B2 expression is highest in the arterial endothelium, whereas EphB4 is expressed most prominently in venous endothelial cells in a variety of animal species and developmental stages (Wang et al. 1998, 2010; Adams et al. 1999; Gerety et al. 1999; Lawson
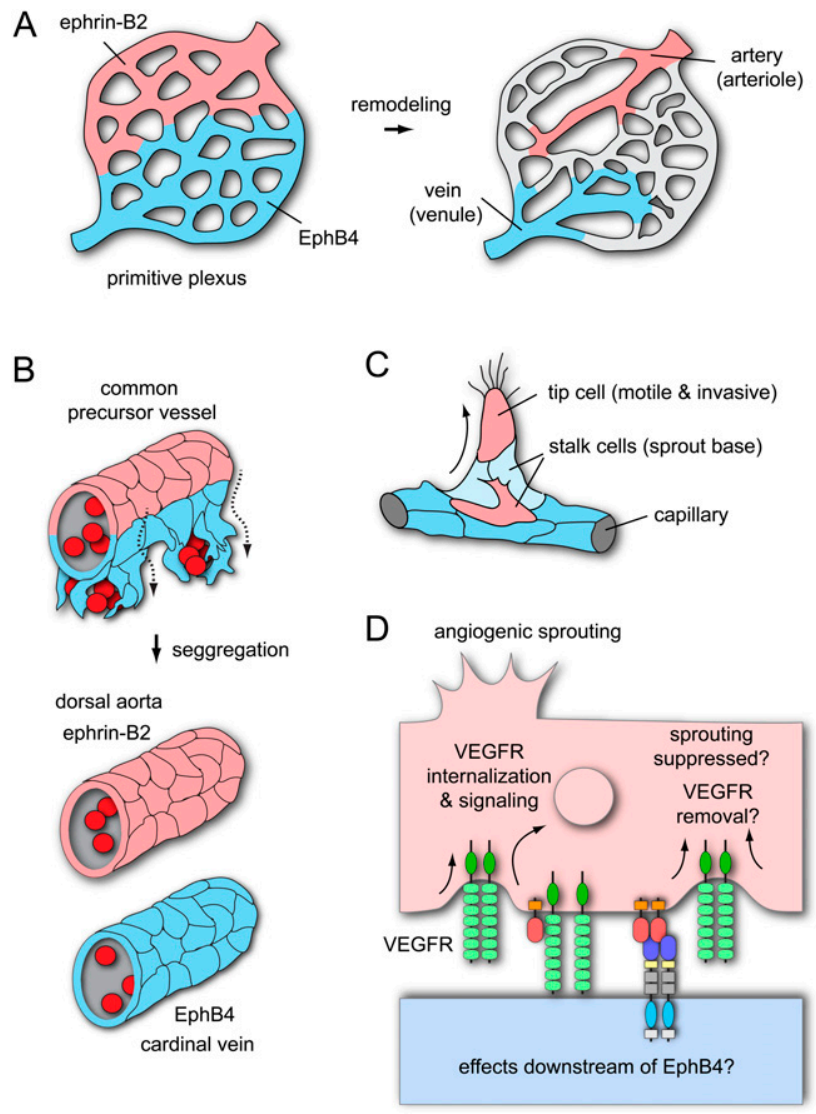

Figure 4. Roles of EphB4 and ephrin-B2 in blood vessel morphogenesis. (A) During vasculogenesis, angioblasts assemble a primitive vascular plexus. Presumptive arterial and venous territories are already marked by complementary expression of ephrin-B2 and EphB4, respectively, before this plexus remodels in arteries (ephrin-B2 ${ }^{+}$), veins $\left(\right.$EphB4 $\left.4^{+}\right)$, and capillaries. $(B)$ In zebrafish embryos, ventral migration of venous-fated cells from a common precursor vessel leads to segregation of the DA $\left(\right.$ ephrin-B2 ${ }^{+}$) from the CV $\left(\mathrm{EphB}^{+}\right)$. (C) Expression of ephrin-B2 (red) in the leading cells of the sprout (so-called tip cells) partially overlaps with EphB4 (blue) in stalk cells at the sprout base. $(D)$ Ephrin-B2 links the regulation of cell motility and invasiveness to VEGF receptor (VEGFR) endocytosis and signaling. The effects downstream from EphB4 in this context remain unknown.

et al. 2001, 2002; Moyon et al. 2001; Othman-Hassan et al. 2001; Salvucci et al. 2006; Sawamiphak et al. 2010). While this makes the two molecules useful markers for arterial-venous differentiation, the complementary expression domains and spatial separation of arteries and veins raises questions about the sites of signaling interactions. Interestingly, ephrin-B2 and EphB4 expression already marks larger regions of the primitive yolk sac plexus prior to remodeling (Wang et al. 1998; Adams et al. 1999; Gerety et al. 1999; Zhong et al. 2001; Gerety and Anderson 2002). Thus, binding of the two molecules might occur at the domain boundaries and thereby promote angiogenesis in the early embryo (Fig. 4A).

Ephrin-B2 and EphB4 are also required for the development of the two major axial vessels transporting blood between the heart and the periphery: the DA and the 
cardinal vein (CV). It was previously thought that these vessels form by the vasculogenic assembly of angioblasts. However, this view has been profoundly challenged by a study in zebrafish embryos that shows that angioblasts initially assemble into only a single axial vessel, termed the common precursor vessel, in the trunk (Herbert et al. 2009). Ventral sprouting from the precursor vessel and the migration of venous-fated endothelial cells leads to a separation of the DA and the CV. Thus, the CV is formed not by vasculogenesis but arterial-venous cell segregation (Fig. 4B). This process is controlled by Eph/ephrin interactions (Herbert et al. 2009). Endothelial cells expressing ephrin-B2a (one of the two orthologs of mammalian ephrin-B2) have limited ability to migrate ventrally, whereas those expressing the venous marker EphB4 (EphB4a) preferentially move into the CV. Fewer cells are retained in the DA when ephrin-B2 expression is targeted with morpholinos or when a C-terminally truncated, reverse signaling-incompetent version of the ligand is overexpressed. Conversely, injection of morpholinos targeting EphB4 reduces the contribution of cells to the CV (Herbert et al. 2009).

Ephrin-B2 expression in the vasculature is positively controlled by vascular endothelial growth factor (VEGF) signaling and the Notch pathway, both of which are critical regulators of vessel growth and arterial differentiation (Torres-Vazquez et al. 2003; Lamont and Childs 2006). VEGF-A; its receptor, Kdrl/VEGFR2; and Notch, all of which are known to upregulate the expression of ephrin-B2, promote DA formation and prevent excessive ventral sprouting. The ventral migration of venous-fated, EphB4-expressing cells and CV formation are positively regulated by VEGF-C (another member of the VEGF family), its receptor Flt4/VEGFR3, and the p110 $\alpha$ catalytic PI3K subunit, all of which enhance endothelial motility. Although it is not yet clear whether the major axial vessels in mammals also develop by segregation from a common precursor, the caliber of the DA and CV in the early mouse embryo is reciprocally balanced by Notch, ephrin-B2, and EphB4. Moreover, the anterior parts of these axial vessels show conspicuous connections that might correspond to migrating endothelial cells (Carlson et al. 2005; Benedito et al. 2008; Kim et al. 2008).

\section{Endothelial sprouting and VEGF receptor endocytosis}

Another site of overlapping EphB4 and ephrin-B2 expression in the embryonic and early postnatal mouse is developing lymphatic vessels. Unlike blood vessels, which carry circulating blood, the lymphatic vasculature is a blind-ended network that transports protein-rich lymph and immune cells unidirectionally from the periphery through lymph nodes into certain veins. Growth of dermal lymphatic vessels involves endothelial sprouting from a primitive plexus, and this process is defective in mutant mice lacking the C-terminal PDZ motif of ephrin-B2 (Makinen et al. 2005). Ephrin-B2 is also an important regulator of endothelial sprouting from blood vessels (Sawamiphak et al. 2010; Wang et al. 2010).
Expression of the ligand labels angiogenic capillaries in the embryonic skin and postnatal retina, where it partially overlaps with EphB4 (Wang et al. 2010). Ephrin-B2 levels are also increased at sites of physiological and pathological neoangiogenesis in the adult (Gale et al. 2001; Shin et al. 2001).

Angiogenic sprouting involves important phenotypic changes in a subset of endothelial cells, termed tip cells, which become motile and invasive, extend filopodial protrusions, and lead the sprout from its distal end (Fig. 4C). Other endothelial cells, the stalk cells, form the base of the sprout and follow the tip cell (Gerhardt et al. 2003). Ephrin-B2, which strongly promotes endothelial cell motility and invasive behavior in cultured cells and transgenic mice, is an important positive regulator of this sprouting process (Bochenek et al. 2010; Sawamiphak et al. 2010; Wang et al. 2010). Physiological and pathological angiogenesis are impaired in inducible loss-offunction mutant mice or, albeit to a lesser extent, in animals lacking the C-terminal PDZ-binding motif in ephrin-B2 (Sawamiphak et al. 2010; Wang et al. 2010). Expression of EphB4 in tumor cells enhances blood vessel growth through interactions with endothelial ephrin-B2 (Noren et al. 2006), which further supports a proangiogenic role of ephrin-B2 reverse signaling.

The distinct behavior of tip versus stalk endothelial cells is strongly coupled to VEGF and Notch signaling. Gradients of VEGF-A in the tissue promote filopodia formation and attract vascular sprouts (Ruhrberg et al. 2002; Gerhardt et al. 2003). The combined action of two Notch ligands, Delta-like 4 and Jagged1, with opposing functional roles in the vasculature confines Notch activation preferentially to stalk cells. This, in turn, is thought to down-regulate the expression of VEGF receptors in the stalk so that these cells respond less to VEGF than those at the sprout tip (Siekmann et al. 2008; Benedito et al. 2009). VEGF signaling has also been linked to trafficking of the receptor VEGFR2 and the dynamin-binding protein synectin/GIPC, which connects actin-based molecular motors to endocytic vesicles (Lanahan et al. 2010). In the absence of synectin, trafficking of VEGFR2-containing endosomes is delayed, the receptor gets selectively dephosphorylated at a critical cytoplasmic tyrosine residue, and the downstream activation of mitogen-activated protein (MAP) kinase signaling is impaired (Lanahan et al. 2010). These findings are consistent with previous evidence for VEGF receptor signaling in endosomes or in an autocrine fashion without VEGF secretion (Lampugnani et al. 2006; Lee et al. 2007).

Interestingly, endothelial ephrin-B2 and its C-terminal PDZ-binding motif are also required for the endocytosis of the receptors VEGFR2 and VEGFR3 in cultured cells or mutant mice (Fig. 4D; Sawamiphak et al. 2010; Wang et al. 2010). In the absence of the B-class ligand, stimulated VEGF receptors are retained on the cell surface, which is accompanied by reduced tyrosine phosphorylation of these molecules and impaired downstream activation of Rac1, Akt, and MAP kinase Erk (Sawamiphak et al. 2010; Wang et al. 2010). While the stimulation of EphB4 forward or ephrin-B2 reverse signaling can trigger some VEGF receptor 
internalization even in the absence of VEGF stimulation, this process fails to induce significant activation of the VEGF pathway (Fig. 4D; Sawamiphak et al. 2010; Wang et al. 2010). Although the exact molecular connection between the Eph/ephrin system and VEGF receptor endocytosis remains to be resolved, the available evidence points to a transient interaction at the plasma membrane early in the endocytosis process (Sawamiphak et al. 2010; Wang et al. 2010). The activation of small Rho family GTPases downstream from endothelial ephrin-B2 (Bochenek et al. 2010) might be important in this context, similar to what has been shown for Eph/ephrin-mediated internalization processes in the nervous system. The link between ephrinB2 and VEGF signaling might also be relevant for the segregation of the DA and $\mathrm{CV}$, which is differentially controlled by VEGF-A, VEGF-C, and the corresponding receptors (Herbert et al. 2009).

\section{Outlook}

Eph receptors and ephrins are highly versatile regulators of processes as diverse as axon guidance, the modulation of synaptic plasticity, cell sorting in the intestinal crypt, or the morphogenesis of the vascular system. These roles are not confined to physiological processes, but are highly relevant for a variety of human pathologies and, in particular, cancer. Thus, understanding the key mechanisms controlling Eph/ephrin function would not only provide deeper insight into interesting biological principles, it might also enable the development of new therapeutic reagents. For example, while antibodies against VEGF-A are already used for the treatment of cancer, inhibition of ephrin-B2 might be useful to simultaneously interfere with the function of VEGFR2 and VEGFR3, which act together during angiogenesis (Tammela et al. 2008).

Unfortunately, factors such as the large number of ligands and receptors, their dynamic expression patterns, the complexity of bidirectional signaling, the strength of their interactions, or the influence of cis versus trans binding complicate the research on Eph/ephrin molecules and can lead to confusing, seemingly incompatible results. For example, it has been shown that Eph/ephrin signaling can modulate integrin activity positively as well as negatively (Becker et al. 2000; Huai and Drescher 2001; Noren et al. 2009; Yamazaki et al. 2009). Another puzzle is the question of how a limited set of receptorligand interactions is translated into highly diverse biological readouts depending on cell type and tissue. Thus, generic activities of the Eph/ephrin system, like the recruitment of specific cytoplasmic adapter and signaling molecules, need to get coupled to cell type-specific molecules with specialized functional roles. The emerging links between Eph/ephrin molecules and endocytosis, which are highlighted in this review, appear to resolve this conundrum by connecting Ephs and ephrins with AMPA-type glutamatergic receptors in neurons or VEGF receptors in endothelial cells. Likewise, it should be worthwhile to search for similar links to the internalization of the receptors for Wnts, FGF and EGF family growth factors, or other key players in the gastrointes- tinal tract, or in other organ systems where little is known about the role of Eph/ephrin-induced endocytosis. In the vasculature or the nervous system, where exciting connections with receptor trafficking have already been established, more insight is needed into the underlying molecular machinery and the association with clathrin, clathrin-binding adapters, molecular motors, and the cytoskeleton. Differential effects of Eph/ephrin molecules on integrins, which are also strongly regulated by trafficking and control the internalization of other surface molecules (Caswell et al. 2009), need to be reexplored in the context of endocytosis.

The internalization of the Eph/ephrin complex or of associated surface receptors might also explain some of the puzzling variation in the experimental results published by different groups. Trans-endocytosis can convert adhesive interactions into repulsion. Likewise, the controlled removal of Ephs and ephrins from the cell surface in response to certain stimuli could lead to fundamental changes in migratory behavior or cell repulsion and sorting processes. The fate of the internalized Eph/ephrin molecules-e.g., degradation versus recycling to the cell surface-and the regulation of the underlying trafficking processes remain to be resolved. Future work should address these and other important questions to resolve whether the control of endocytosis is one of the general mechanisms responsible for Eph/ephrin function in highly diverse biological settings.

\section{Acknowledgments}

We thank the Max Planck Society and the University of Muenster for financial support, and members of the Department of Tissue Morphogenesis for stimulating discussions.

\section{References}

Adams RH, Wilkinson GA, Weiss C, Diella F, Gale NW, Deutsch U, Risau W, Klein R. 1999. Roles of ephrinB ligands and EphB receptors in cardiovascular development: Demarcation of arterial/venous domains, vascular morphogenesis, and sprouting angiogenesis. Genes Dev 13: 295-306.

Batlle E, Henderson JT, Beghtel H, van den Born MM, Sancho E, Huls G, Meeldijk J, Robertson J, van de Wetering M, Pawson $\mathrm{T}$, et al. 2002. $\beta$-Catenin and TCF mediate cell positioning in the intestinal epithelium by controlling the expression of EphB/ephrinB. Cell 111: 251-263.

Batlle E, Bacani J, Begthel H, Jonkheer S, Gregorieff A, van de Born M, Malats N, Sancho E, Boon E, Pawson T, et al. 2005. EphB receptor activity suppresses colorectal cancer progression. Nature 435: 1126-1130.

Becker E, Huynh-Do U, Holland S, Pawson T, Daniel TO, Skolnik EY. 2000. Nck-interacting Ste20 kinase couples Eph receptors to c-Jun $\mathrm{N}$-terminal kinase and integrin activation. Mol Cell Biol 20: 1537-1545.

Benedito R, Trindade A, Hirashima M, Henrique D, da Costa LL, Rossant J, Gill PS, Duarte A. 2008. Loss of Notch signalling induced by Dll4 causes arterial calibre reduction by increasing endothelial cell response to angiogenic stimuli. $B M C$ Dev Biol 8: 117. doi: 10.1186/1471-213X-8-117.

Benedito R, Roca C, Sorensen I, Adams S, Gossler A, Fruttiger M, Adams RH. 2009. The notch ligands Dll4 and Jagged1 have opposing effects on angiogenesis. Cell 137: 1124-1135. 
Bochenek ML, Dickinson S, Astin JW, Adams RH, Nobes CD. 2010. Ephrin-B2 regulates endothelial cell morphology and motility independently of Eph-receptor binding. I Cell Sci 123: $1235-1246$.

Brantley-Sieders DM, Caughron J, Hicks D, Pozzi A, Ruiz JC, Chen J. 2004. EphA2 receptor tyrosine kinase regulates endothelial cell migration and vascular assembly through phosphoinositide 3-kinase-mediated Racl GTPase activation. J Cell Sci 117: 2037-2049.

Bruckner K, Pablo Labrador J, Scheiffele P, Herb A, Seeburg PH, Klein R. 1999. EphrinB ligands recruit GRIP family PDZ adaptor proteins into raft membrane microdomains. Neuron 22: $511-524$.

Bruns RR, Palade GE. 1968. Studies on blood capillaries. I. General organization of blood capillaries in muscle. I Cell Biol 37: 244-276.

Carlson TR, Yan Y, Wu X, Lam MT, Tang GL, Beverly LJ, Messina LM, Capobianco AJ, Werb Z, Wang R. 2005. Endothelial expression of constitutively active Notch4 elicits reversible arteriovenous malformations in adult mice. Proc Natl Acad Sci 102: 9884-9889.

Carvalho RF, Beutler M, Marler KJ, Knoll B, Becker-Barroso E, Heintzmann R, Ng T, Drescher U. 2006. Silencing of EphA3 through a cis interaction with ephrinA5. Nat Neurosci 9: 322-330.

Casali A, Batlle E. 2009. Intestinal stem cells in mammals and Drosophila. Cell Stem Cell 4: 124-127.

Caswell PT, Vadrevu S, Norman JC. 2009. Integrins: Masters and slaves of endocytic transport. Nat Rev Mol Cell Biol 10: 843853.

Chisholm A, Tessier-Lavigne M. 1999. Conservation and divergence of axon guidance mechanisms. Curr Opin Neurobiol 9: 603-615.

Clevers H, Batlle E. 2006. EphB/EphrinB receptors and Wnt signaling in colorectal cancer. Cancer Res 66: 2-5.

Compagni A, Logan M, Klein R, Adams RH. 2003. Control of skeletal patterning by ephrinB1-EphB interactions. Dev Cell 5: 217-230.

Cortina C, Palomo-Ponce S, Iglesias M, Fernandez-Masip JL, Vivancos A, Whissell G, Huma M, Peiro N, Gallego L, Jonkheer $\mathrm{S}$, et al. 2007. EphB-ephrin-B interactions suppress colorectal cancer progression by compartmentalizing tumor cells. Nat Genet 39: 1376-1383.

Cowan CW, Shao YR, Sahin M, Shamah SM, Lin MZ, Greer PL, Gao S, Griffith EC, Brugge JS, Greenberg ME. 2005. Vav family GEFs link activated Ephs to endocytosis and axon guidance. Neuron 46: 205-217.

Crosnier C, Stamataki D, Lewis J. 2006. Organizing cell renewal in the intestine: Stem cells, signals and combinatorial control. Nat Rev Genet 7: 349-359.

Davy A, Robbins SM. 2000. Ephrin-A5 modulates cell adhesion and morphology in an integrin-dependent manner. EMBO I 19: 5396-5405.

Davy A, Gale NW, Murray EW, Klinghoffer RA, Soriano P, Feuerstein C, Robbins SM. 1999. Compartmentalized signaling by GPI-anchored ephrin-A5 requires the Fyn tyrosine kinase to regulate cellular adhesion. Genes Dev 13: 3125-3135.

Davy A, Aubin J, Soriano P. 2004. Ephrin-B1 forward and reverse signaling are required during mouse development. Genes Dev 18: $572-583$.

Davy A, Bush JO, Soriano P. 2006. Inhibition of gap junction communication at ectopic Eph/ephrin boundaries underlies craniofrontonasal syndrome. PLOS Biol 4: e315. doi: 10.1371/ journal.pbio.0040315.

Deininger K, Eder M, Kramer ER, Zieglgansberger W, Dodt HU, Dornmair K, Colicelli J, Klein R. 2008. The Rab5 guanylate exchange factor Rin1 regulates endocytosis of the EphA4 receptor in mature excitatory neurons. Proc Natl Acad Sci 105: 12539-12544.

Dopeso H, Mateo-Lozano S, Mazzolini R, Rodrigues P, LagaresTena L, Ceron J, Romero J, Esteves M, Landolfi S, HernandezLosa J, et al. 2009. The receptor tyrosine kinase EPHB4 has tumor suppressor activities in intestinal tumorigenesis. Cancer Res 69: 7430-7438.

Egea J, Klein R. 2007. Bidirectional Eph-ephrin signaling during axon guidance. Trends Cell Biol 17: 230-238.

Essmann CL, Martinez E, Geiger JC, Zimmer M, Traut MH, Stein V, Klein R, Acker-Palmer A. 2008. Serine phosphorylation of ephrinB2 regulates trafficking of synaptic AMPA receptors. Nat Neurosci 11: 1035-1043.

Flanagan JG. 2006. Neural map specification by gradients. Curr Opin Neurobiol 16: 59-66.

Flanagan JG, Vanderhaeghen P. 1998. The ephrins and Eph receptors in neural development. Annu Rev Neurosci 21: 309-345.

Foo SS, Turner CJ, Adams S, Compagni A, Aubyn D, Kogata N, Lindblom P, Shani M, Zicha D, Adams RH. 2006. Ephrin-B2 controls cell motility and adhesion during blood-vessel-wall assembly. Cell 124: 161-173.

Gale NW, Baluk P, Pan L, Kwan M, Holash J, DeChiara TM, McDonald DM, Yancopoulos GD. 2001. Ephrin-B2 selectively marks arterial vessels and neovascularization sites in the adult, with expression in both endothelial and smooth-muscle cells. Dev Biol 230: 151-160.

Genander M, Halford MM, Xu NJ, Eriksson M, Yu Z, Qiu Z, Martling A, Greicius G, Thakar S, Catchpole T, et al. 2009. Dissociation of EphB2 signaling pathways mediating progenitor cell proliferation and tumor suppression. Cell 139: 679-692.

Georgakopoulos A, Litterst C, Ghersi E, Baki L, Xu C, Serban G, Robakis NK. 2006. Metalloproteinase/Presenilin1 processing of ephrinB regulates EphB-induced Src phosphorylation and signaling. EMBO I 25: 1242-1252.

Gerety SS, Anderson DJ. 2002. Cardiovascular ephrinB2 function is essential for embryonic angiogenesis. Development 129: $1397-1410$

Gerety SS, Wang HU, Chen ZF, Anderson DJ. 1999. Symmetrical mutant phenotypes of the receptor EphB4 and its specific transmembrane ligand ephrin-B2 in cardiovascular development. Mol Cell 4: 403-414.

Gerhardt H, Golding M, Fruttiger M, Ruhrberg C, Lundkvist A, Abramsson A, Jeltsch M, Mitchell C, Alitalo K, Shima D, et al. 2003. VEGF guides angiogenic sprouting utilizing endothelial tip cell filopodia. J Cell Biol 161: 1163-1177.

Gong LW, De Camilli P. 2008. Regulation of postsynaptic AMPA responses by synaptojanin 1. Proc Natl Acad Sci 105: 1756117566.

Groeger G, Nobes CD. 2007. Co-operative Cdc42 and Rho signalling mediates ephrinB-triggered endothelial cell retraction. Biochem J 404: 23-29.

Grunwald IC, Klein R. 2002. Axon guidance: Receptor complexes and signaling mechanisms. Curr Opin Neurobiol 12: 250-259.

Grunwald IC, Korte M, Adelmann G, Plueck A, Kullander K, Adams RH, Frotscher M, Bonhoeffer T, Klein R. 2004. Hippocampal plasticity requires postsynaptic ephrinBs. Nat Neurosci 7: 33-40.

Hansen MJ, Dallal GE, Flanagan JG. 2004. Retinal axon response to ephrin-as shows a graded, concentration-dependent transition from growth promotion to inhibition. Neuron 42: $717-$ 730 . 
Hattori M, Osterfield M, Flanagan JG. 2000. Regulated cleavage of a contact-mediated axon repellent. Science 289: 13601365.

Herbert SP, Huisken J, Kim TN, Feldman ME, Houseman BT, Wang RA, Shokat KM, Stainier DY. 2009. Arterial-venous segregation by selective cell sprouting: An alternative mode of blood vessel formation. Science 326: 294-298.

Himanen JP, Chumley MJ, Lackmann M, Li C, Barton WA, Jeffrey PD, Vearing C, Geleick D, Feldheim DA, Boyd AW, et al. 2004. Repelling class discrimination: ephrin-A5 binds to and activates EphB2 receptor signaling. Nat Neurosci 7: 501-509.

Himanen JP, Saha N, Nikolov DB. 2007. Cell-cell signaling via Eph receptors and ephrins. Curr Opin Cell Biol 19: 534-542.

Hirbec H, Perestenko O, Nishimune A, Meyer G, Nakanishi S, Henley JM, Dev KK. 2002. The PDZ proteins PICK1, GRIP, and syntenin bind multiple glutamate receptor subtypes. Analysis of PDZ binding motifs. I Biol Chem 277: 1522115224.

Hirbec H, Francis JC, Lauri SE, Braithwaite SP, Coussen F, Mulle C, Dev KK, Coutinho V, Meyer G, Isaac JT, et al. 2003. Rapid and differential regulation of AMPA and kainate receptors at hippocampal mossy fibre synapses by PICK1 and GRIP. Neuron 37: 625-638.

Holen HL, Shadidi M, Narvhus K, Kjosnes O, Tierens A, Aasheim HC. 2008. Signaling through ephrin-A ligand leads to activation of Src-family kinases, Akt phosphorylation, and inhibition of antigen receptor-induced apoptosis. I Leukoc Biol 84: 1183-1191.

Holmberg J, Clarke DL, Frisen J. 2000. Regulation of repulsion versus adhesion by different splice forms of an Eph receptor. Nature 408: 203-206.

Holmberg J, Genander M, Halford MM, Anneren C, Sondell M, Chumley MJ, Silvany RE, Henkemeyer M, Frisen J. 2006. EphB receptors coordinate migration and proliferation in the intestinal stem cell niche. Cell 125: 1151-1163.

Hopper NA, O'Connor V. 2005. Ephrin tempers two-faced synaptojanin 1. Nat Cell Biol 7: 454-456.

Hornberger MR, Dutting D, Ciossek T, Yamada T, Handwerker C, Lang S, Weth F, Huf J, Wessel R, Logan C, et al. 1999. Modulation of EphA receptor function by coexpressed ephrinA ligands on retinal ganglion cell axons. Neuron 22: 731742.

Huai J, Drescher U. 2001. An ephrin-A-dependent signaling pathway controls integrin function and is linked to the tyrosine phosphorylation of a $120-\mathrm{kDa}$ protein. J Biol Chem 276: 6689-6694.

Irie F, Yamaguchi Y. 2002. EphB receptors regulate dendritic spine development via intersectin, Cdc42 and N-WASP. Nat Neurosci 5: 1117-1118.

Irie F, Okuno M, Pasquale EB, Yamaguchi Y. 2005. EphrinBEphB signalling regulates clathrin-mediated endocytosis through tyrosine phosphorylation of synaptojanin 1. Nat Cell Biol 7: 501-509.

Iwasato $\mathrm{T}$, Katoh $\mathrm{H}$, Nishimaru $\mathrm{H}$, Ishikawa $\mathrm{Y}$, Inoue $\mathrm{H}$, Saito YM, Ando R, Iwama M, Takahashi R, Negishi M, et al. 2007. Rac-GAP $\alpha$-chimerin regulates motor-circuit formation as a key mediator of EphrinB3/EphA4 forward signaling. Cell 130: 742-753.

Janes PW, Saha N, Barton WA, Kolev MV, Wimmer-Kleikamp SH, Nievergall E, Blobel CP, Himanen JP, Lackmann M, Nikolov DB. 2005. Adam meets Eph: An ADAM substrate recognition module acts as a molecular switch for ephrin cleavage in trans. Cell 123: 291-304.

Janes PW, Wimmer-Kleikamp SH, Frangakis AS, Treble K, Griesshaber B, Sabet O, Grabenbauer M, Ting AY, Saftig P,
Bastiaens PI, et al. 2009. Cytoplasmic relaxation of active Eph controls ephrin shedding by ADAM10. PLoS Biol 7: e1000215. doi: 10.1371/journal.pbio.1000215.

Jorgensen C, Sherman A, Chen GI, Pasculescu A, Poliakov A, Hsiung M, Larsen B, Wilkinson DG, Linding R, Pawson T. 2009. Cell-specific information processing in segregating populations of Eph receptor ephrin-expressing cells. Science 326: 1502-1509.

Kida YS, Sato T, Miyasaka KY, Suto A, Ogura T. 2007. Daam1 regulates the endocytosis of EphB during the convergent extension of the zebrafish notochord. Proc Natl Acad Sci 104: 6708-6713.

Kim YH, Hu H, Guevara-Gallardo S, Lam MT, Fong SY, Wang RA. 2008. Artery and vein size is balanced by Notch and ephrin B2/EphB4 during angiogenesis. Development 135: 3755-3764.

Klein R. 2004. Eph/ephrin signaling in morphogenesis, neural development and plasticity. Curr Opin Cell Biol 16: 580-589.

Klein R. 2009. Bidirectional modulation of synaptic functions by Eph/ephrin signaling. Nat Neurosci 12: 15-20.

Koh TW, Verstreken P, Bellen HJ. 2004. Dap160/intersectin acts as a stabilizing scaffold required for synaptic development and vesicle endocytosis. Neuron 43: 193-205.

Kullander K, Klein R. 2002. Mechanisms and functions of Eph and ephrin signalling. Nat Rev Mol Cell Biol 3: 475-486.

Lai KO, Ip NY. 2009. Synapse development and plasticity: Roles of ephrin/Eph receptor signaling. Curr Opin Neurobiol 19: 275-283.

Lamont RE, Childs S. 2006. MAPping out arteries and veins. Sci STKE 2006: pe39. doi: 10.1126/stke.3552006pe39.

Lampugnani MG, Orsenigo F, Gagliani MC, Tacchetti C, Dejana E. 2006. Vascular endothelial cadherin controls VEGFR-2 internalization and signaling from intracellular compartments. J Cell Biol 174: 593-604.

Lanahan AA, Hermans K, Claes F, Kerley-Hamilton JS, Zhuang ZW, Giordano FJ, Carmeliet P, Simons M. 2010. VEGF receptor 2 endocytic trafficking regulates arterial morphogenesis. Dev Cell 18: 713-724.

Lauterbach J, Klein R. 2006. Release of full-length EphB2 receptors from hippocampal neurons to cocultured glial cells. J Neurosci 26: 11575-11581.

Lawson ND, Scheer N, Pham VN, Kim CH, Chitnis $A B$, Campos-Ortega JA, Weinstein BM. 2001. Notch signaling is required for arterial-venous differentiation during embryonic vascular development. Development 128: 3675-3683.

Lawson ND, Vogel AM, Weinstein BM. 2002. sonic hedgehog and vascular endothelial growth factor act upstream of the Notch pathway during arterial endothelial differentiation. Dev Cell 3: 127-136.

Lee S, Chen TT, Barber CL, Jordan MC, Murdock J, Desai S, Ferrara N, Nagy A, Roos KP, Iruela-Arispe ML. 2007. Autocrine VEGF signaling is required for vascular homeostasis. Cell 130: 691-703.

Li HS, Wang D, Shen Q, Schonemann MD, Gorski JA, Jones KR, Temple S, Jan LY, Jan YN. 2003. Inactivation of Numb and Numblike in embryonic dorsal forebrain impairs neurogenesis and disrupts cortical morphogenesis. Neuron 40: 11051118.

Lim YS, McLaughlin T, Sung TC, Santiago A, Lee KF, O'Leary DD. 2008. p75(NTR) mediates ephrin-A reverse signaling required for axon repulsion and mapping. Neuron 59: 746-758.

Litterst C, Georgakopoulos A, Shioi J, Ghersi E, Wisniewski T, Wang R, Ludwig A, Robakis NK. 2007. Ligand binding and calcium influx induce distinct ectodomain $/ \gamma$-secretase-processing pathways of EphB2 receptor. I Biol Chem 282: 16155-16163. 
Lu W, Ziff EB. 2005. PICK1 interacts with ABP/GRIP to regulate AMPA receptor trafficking. Neuron 47: 407-421.

Maisner A, Neufeld J, Weingartl H. 2009. Organ- and endotheliotropism of Nipah virus infections in vivo and in vitro. Thromb Haemost 102: 1014-1023.

Makinen T, Adams RH, Bailey J, Lu Q, Ziemiecki A, Alitalo K, Klein R, Wilkinson GA. 2005. PDZ interaction site in ephrinB2 is required for the remodeling of lymphatic vasculature. Genes Dev 19: 397-410.

Mann F, Miranda E, Weinl C, Harmer E, Holt CE. 2003. B-type Eph receptors and ephrins induce growth cone collapse through distinct intracellular pathways. I Neurobiol 57: 323-336.

Marie B, Sweeney ST, Poskanzer KE, Roos J, Kelly RB, Davis GW. 2004. Dap160/intersectin scaffolds the periactive zone to achieve high-fidelity endocytosis and normal synaptic growth. Neuron 43: 207-219.

Marler KJ, Becker-Barroso E, Martinez A, Llovera M, Wentzel C, Poopalasundaram S, Hindges R, Soriano E, Comella J, Drescher U. 2008. A TrkB/EphrinA interaction controls retinal axon branching and synaptogenesis. I Neurosci 28: 12700-12712.

Marquardt T, Shirasaki R, Ghosh S, Andrews SE, Carter N, Hunter T, Pfaff SL. 2005. Coexpressed EphA receptors and ephrin-A ligands mediate opposing actions on growth cone navigation from distinct membrane domains. Cell 121: 127139.

Marston DJ, Dickinson S, Nobes CD. 2003. Rac-dependent trans-endocytosis of ephrinBs regulates Eph-ephrin contact repulsion. Nat Cell Biol 5: 879-888.

McClelland AC, Sheffler-Collins SI, Kayser MS, Dalva MB. 2009. Ephrin-B1 and ephrin-B2 mediate EphB-dependent presynaptic development via syntenin-1. Proc Natl Acad Sci 106: 20487-20492.

Moyon D, Pardanaud L, Yuan L, Breant C, Eichmann A. 2001. Plasticity of endothelial cells during arterial-venous differentiation in the avian embryo. Development 128: 33593370.

Nakada M, Drake KL, Nakada S, Niska JA, Berens ME. 2006. Ephrin-B3 ligand promotes glioma invasion through activation of Rac1. Cancer Res 66: 8492-8500.

Nishimura T, Fukata Y, Kato K, Yamaguchi T, Matsuura Y, Kamiguchi H, Kaibuchi K. 2003. CRMP-2 regulates polarized Numb-mediated endocytosis for axon growth. Nat Cell Biol 5: 819-826.

Nishimura T, Yamaguchi T, Tokunaga A, Hara A, Hamaguchi T, Kato K, Iwamatsu A, Okano H, Kaibuchi K. 2006. Role of numb in dendritic spine development with a Cdc42 GEF intersectin and EphB2. Mol Biol Cell 17: 1273-1285.

Noren NK, Pasquale EB. 2004. Eph receptor-ephrin bidirectional signals that target Ras and Rho proteins. Cell Signal 16: 655666.

Noren NK, Foos G, Hauser CA, Pasquale EB. 2006. The EphB4 receptor suppresses breast cancer cell tumorigenicity through an Abl-Crk pathway. Nat Cell Biol 8: 815-825.

Noren NK, Yang NY, Silldorff M, Mutyala R, Pasquale EB. 2009. Ephrin-independent regulation of cell substrate adhesion by the EphB4 receptor. Biochem J 422: 433-442.

Othman-Hassan K, Patel K, Papoutsi M, Rodriguez-Niedenfuhr M, Christ B, Wilting J. 2001. Arterial identity of endothelial cells is controlled by local cues. Dev Biol 237: 398-409.

Palamidessi A, Frittoli E, Garre M, Faretta M, Mione M, Testa I, Diaspro A, Lanzetti L, Scita G, Di Fiore PP. 2008. Endocytic trafficking of $\mathrm{Rac}$ is required for the spatial restriction of signaling in cell migration. Cell 134: 135-147.
Parker M, Roberts R, Enriquez M, Zhao X, Takahashi T, Pat Cerretti D, Daniel T, Chen J. 2004. Reverse endocytosis of transmembrane ephrin-B ligands via a clathrin-mediated pathway. Biochem Biophys Res Commun 323: 17-23.

Pasquale EB. 2005. Eph receptor signalling casts a wide net on cell behaviour. Nat Rev Mol Cell Biol 6: 462-475.

Pasquale EB. 2010. Eph receptors and ephrins in cancer: Bidirectional signalling and beyond. Nat Rev Cancer 10: 165180.

Passante L, Gaspard N, Degraeve M, Frisen J, Kullander K, De Maertelaer V, Vanderhaeghen P. 2008. Temporal regulation of ephrin/Eph signalling is required for the spatial patterning of the mammalian striatum. Development 135: 3281-3290.

Petersen PH, Zou K, Hwang JK, Jan YN, Zhong W. 2002. Progenitor cell maintenance requires numb and numblike during mouse neurogenesis. Nature 419: 929-934.

Poliakov A, Cotrina M, Wilkinson DG. 2004. Diverse roles of eph receptors and ephrins in the regulation of cell migration and tissue assembly. Dev Cell 7: 465-480.

Risau W. 1997. Mechanisms of angiogenesis. Nature 386: 671674.

Risau W, Flamme I. 1995. Vasculogenesis. Annu Rev Cell Dev Biol 11: 73-91.

Ruhrberg C, Gerhardt H, Golding M, Watson R, Ioannidou S, Fujisawa H, Betsholtz C, Shima DT. 2002. Spatially restricted patterning cues provided by heparin-binding VEGF-A control blood vessel branching morphogenesis. Genes Dev 16: 2684 2698.

Sahin M, Greer PL, Lin MZ, Poucher H, Eberhart J, Schmidt S, Wright TM, Shamah SM, O'Connell S, Cowan CW, et al. 2005. Eph-dependent tyrosine phosphorylation of ephexin1 modulates growth cone collapse. Neuron 46: 191-204.

Salvucci O, de la Luz Sierra M, Martina JA, McCormick PJ, Tosato G. 2006. EphB2 and EphB4 receptors forward signaling promotes SDF-1-induced endothelial cell chemotaxis and branching remodeling. Blood 108: 2914-2922.

Sansom OJ, Reed KR, Hayes AJ, Ireland $\mathrm{H}$, Brinkmann $\mathrm{H}$, Newton IP, Batlle E, Simon-Assmann P, Clevers H, Nathke IS, et al. 2004. Loss of Apc in vivo immediately perturbs Wnt signaling, differentiation, and migration. Genes Dev 18: 1385-1390.

Santolini E, Puri C, Salcini AE, Gagliani MC, Pelicci PG, Tacchetti C, Di Fiore PP. 2000. Numb is an endocytic protein. J Cell Biol 151: 1345-1352.

Sawamiphak S, Seidel S, Essmann CL, Wilkinson GA, Pitulescu ME, Acker T, Acker-Palmer A. 2010. Ephrin-B2 regulates VEGFR2 function in developmental and tumour angiogenesis. Nature 465: 487-491.

Segura I, Essmann CL, Weinges S, Acker-Palmer A. 2007. Grb4 and GIT1 transduce ephrinB reverse signals modulating spine morphogenesis and synapse formation. Nat Neurosci 10: 301-310.

Shamah SM, Lin MZ, Goldberg JL, Estrach S, Sahin M, Hu L, Bazalakova M, Neve RL, Corfas G, Debant A, et al. 2001. EphA receptors regulate growth cone dynamics through the novel guanine nucleotide exchange factor ephexin. Cell 105: 233-244.

Shin D, Garcia-Cardena G, Hayashi S, Gerety S, Asahara T, Stavrakis G, Isner J, Folkman J, Gimbrone MA Jr, Anderson DJ. 2001. Expression of ephrinB2 identifies a stable genetic difference between arterial and venous vascular smooth muscle as well as endothelial cells, and marks subsets of microvessels at sites of adult neovascularization. Dev Biol 230: $139-150$. 
Siekmann AF, Covassin L, Lawson ND. 2008. Modulation of VEGF signalling output by the Notch pathway. Bioessays 30: 303-313.

Spacek J, Harris KM. 2004. Trans-endocytosis via spinules in adult rat hippocampus. I Neurosci 24: 4233-4241.

Tammela T, Zarkada G, Wallgard E, Murtomaki A, Suchting S, Wirzenius M, Waltari M, Hellstrom M, Schomber T, Peltonen $\mathrm{R}$, et al. 2008. Blocking VEGFR-3 suppresses angiogenic sprouting and vascular network formation. Nature 454: 656-660.

Tanaka M, Kamo T, Ota S, Sugimura H. 2003. Association of Dishevelled with Eph tyrosine kinase receptor and ephrin mediates cell repulsion. EMBO J 22: 847-858.

Tanaka M, Ohashi R, Nakamura R, Shinmura K, Kamo T, Sakai R, Sugimura H. 2004. Tiaml mediates neurite outgrowth induced by ephrin-B1 and EphA2. EMBO J 23: 1075-1088.

Tolias KF, Bikoff JB, Kane CG, Tolias CS, Hu L, Greenberg ME. 2007. The Rac1 guanine nucleotide exchange factor Tiam1 mediates EphB receptor-dependent dendritic spine development. Proc Natl Acad Sci 104: 7265-7270.

Tomita T, Tanaka S, Morohashi Y, Iwatsubo T. 2006. Presenilindependent intramembrane cleavage of ephrin-B1. Mol Neurodegener 1: 2.

Torres R, Firestein BL, Dong $\mathrm{H}$, Staudinger J, Olson EN, Huganir RL, Bredt DS, Gale NW, Yancopoulos GD. 1998. PDZ proteins bind, cluster, and synaptically colocalize with Eph receptors and their ephrin ligands. Neuron 21: 1453 1463.

Torres-Vazquez J, Kamei M, Weinstein BM. 2003. Molecular distinction between arteries and veins. Cell Tissue Res 314: 43-59.

van de Wetering M, Sancho E, Verweij C, de Lau W, Oving I, Hurlstone A, van der Horn K, Batlle E, Coudreuse D, Haramis AP, et al. 2002. The $\beta$-catenin/TCF-4 complex imposes a crypt progenitor phenotype on colorectal cancer cells. Cell 111: 241-250.

van der Flier LG, Clevers H. 2009. Stem cells, self-renewal, and differentiation in the intestinal epithelium. Annu Rev Physiol 71: 241-260.

Vihanto MM, Vindis C, Djonov V, Cerretti DP, Huynh-Do U. 2006. Caveolin-1 is required for signaling and membrane targeting of EphB1 receptor tyrosine kinase. J Cell Sci 119: 2299-2309.

Wang HU, Chen ZF, Anderson DJ. 1998. Molecular distinction and angiogenic interaction between embryonic arteries and veins revealed by ephrin-B2 and its receptor Eph-B4. Cell 93: 741-753.

Wang Y, Nakayama M, Pitulescu ME, Schmidt TS, Bochenek ML, Sakakibara A, Adams S, Davy A, Deutsch U, Luthi U, et al. 2010. Ephrin-B2 controls VEGF-induced angiogenesis and lymphangiogenesis. Nature 465: 483-486.

Wimmer-Kleikamp SH, Janes PW, Squire A, Bastiaens PI, Lackmann M. 2004. Recruitment of Eph receptors into signaling clusters does not require ephrin contact. I Cell Biol 164: 661-666.

Xu NJ, Henkemeyer M. 2009. Ephrin-B3 reverse signaling through Grb4 and cytoskeletal regulators mediates axon pruning. Nat Neurosci 12: 268-276.

Xu Q, Mellitzer G, Robinson V, Wilkinson DG. 1999. In vivo cell sorting in complementary segmental domains mediated by Eph receptors and ephrins. Nature 399: 267-271.

Xu Q, Mellitzer G, Wilkinson DG. 2000. Roles of Eph receptors and ephrins in segmental patterning. Philos Trans $R$ Soc Lond B Biol Sci 355: 993-1002.
Yamazaki T, Masuda J, Omori T, Usui R, Akiyama H, Maru Y. 2009. EphA1 interacts with integrin-linked kinase and regulates cell morphology and motility. J Cell Sci 122: 243-255.

Yin Y, Yamashita Y, Noda H, Okafuji T, Go MJ, Tanaka H. 2004. EphA receptor tyrosine kinases interact with co-expressed ephrin-A ligands in cis. Neurosci Res 48: 285-296.

Yoo S, Shin J, Park S. 2010. EphA8-ephrinA5 signaling and clathrin-mediated endocytosis is regulated by Tiam-1, a Rac-specific guanine nucleotide exchange factor. Mol Cells 29: 603-609.

Yu TW, Bargmann CI. 2001. Dynamic regulation of axon guidance. Nat Neurosci 4: 1169-1176.

Yu J, Bergaya S, Murata T, Alp IF, Bauer MP, Lin MI, Drab M, Kurzchalia TV, Stan RV, Sessa WC. 2006. Direct evidence for the role of caveolin-1 and caveolae in mechanotransduction and remodeling of blood vessels. I Clin Invest 116: 12841291.

Zhong TP, Childs S, Leu JP, Fishman MC. 2001. Gridlock signalling pathway fashions the first embryonic artery. Nature 414: 216-220.

Zhuang G, Hunter S, Hwang Y, Chen J. 2007. Regulation of EphA2 receptor endocytosis by SHIP2 lipid phosphatase via phosphatidylinositol 3-kinase-dependent Rac1 activation. I Biol Chem 282: 2683-2694.

Zimmer M, Palmer A, Kohler J, Klein R. 2003. EphB-ephrinB bi-directional endocytosis terminates adhesion allowing contact mediated repulsion. Nat Cell Biol 5: 869-878. 


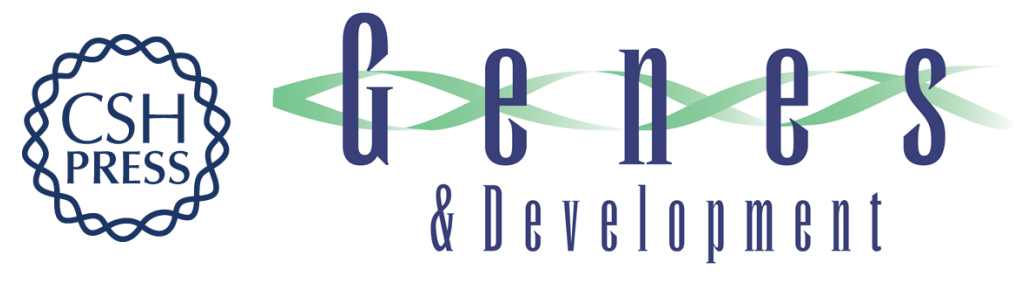

\section{Eph/ephrin molecules--a hub for signaling and endocytosis}

\section{Mara E. Pitulescu and Ralf H. Adams}

Genes Dev. 2010, 24:

Access the most recent version at doi:10.1101/gad.1973910

References This article cites 138 articles, 46 of which can be accessed free at: http://genesdev.cshlp.org/content/24/22/2480.full.html\#ref-list-1

License Freely available online through the Genes \& Development Open Access option.

Email Alerting Receive free email alerts when new articles cite this article - sign up in the box at the top Service right corner of the article or click here.

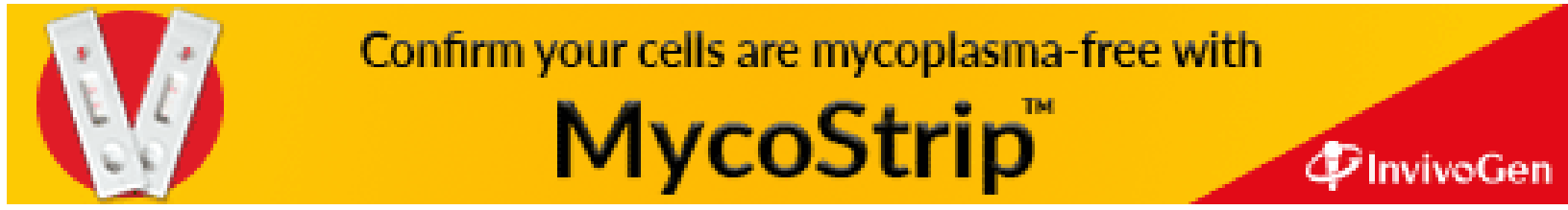

